\author{
Abstract Submission Opens \\ September 15, 2015 \\ Abstract Submission Deadline \\ October 15, 2015
}

\section{CHARACTERIZATION AND MODELING OF MATERIALS}

CM1 New Frontiers in Aberration Corrected Transmission Electron Microscopy CM2 Quantitative Tomography for Materials Research

CM3 Mechanics and Tribology at the NanoscaleIn Situ and In Silico Investigations

CM4 Verification, Validation and Uncertainty Quantification in Multiscale Materials Simulation

\section{ENERGY AND ENVIRONIMENT}

EE1 Emerging Materials and Phenomena for Solar Energy Conversion

EE2 Advancements in Solar Fuels GenerationMaterials, Devices and Systems

EE3 Materials and Devices for Full Spectrum Solar Energy Harvesting

EE4 Electrode Materials and Electrolytes for Lithium and Sodium Ion Batteries

EE5 Next-Generation Electrical Energy Storage Chemistries

EE6 Research Frontiers on Liquid-Solid Interfaces in Electrochemical Energy Storage and Conversion Systems

EE7 Mechanics of Energy Storage and ConversionBatteries, Thermoelectrics and Fuel Cells

EE8 Grid-Scale Energy Storage

EE9 Hydrogen and Fuel Cell Technologies for TransportationMaterials, Systems and Infrastructure

EE10 Recent Advances in Materials for Carbon Capture

EE11 Caloric Materials for Renewable Energy Applications

EE12 Radiation Damage in Materials-A Grand Multiscale Challenge

EE13 Actinides-Fundamental Science, Applications and Technology

EE14 Titanium Oxides-From Fundamental Understanding to Applications

EE15 Materials for Sustainable Development-Integrated Approaches

\section{www.mrs.org/spring2016}

\section{Meeting Chairs}

Christopher A. Bower X-Celeprint Ltd.

Andrew M. Minor University of California, Berkeley

Lawrence Berkeley National Laboratory

Roger Narayan UNC/NCSU Joint Department

of Biomedical Engineering

Izabela Szlufarska University of Wisconsin-Madison

Osamu Ueda Kanazawa Institute of Technology

\section{Don't Miss These Future MRS Meetings!}

2016 MRS Fall Meeting \& Exhibit November 27 - December 2, 2016 Boston, Massachusetts

\section{MRS Spring Meeting \& Exhibit} April $17-21,2017$

Phoenix, Arizona

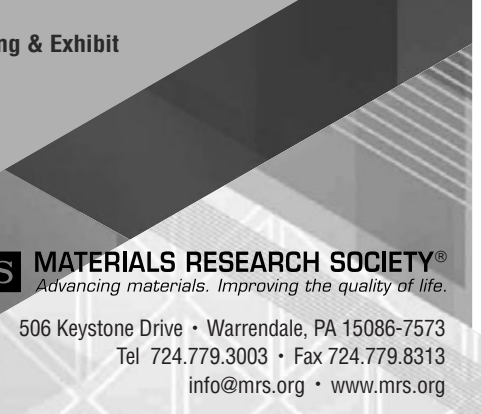

\section{ELECTRONICS AND PHOTONICS}

EP1 Organic Excitonic Systems and Devices

EP2 Silicon Carbide-Substrates, Epitaxy, Devices, Circuits and Graphene

EP3 Perovskite-Based Photovoltaics and Optoelectronic Devices

EP4 Emerging Silicon Science and Technology

EP5 Metal Oxide Hetero-Interfaces in Hybrid Electronic Platforms

EP6 Integration of Heterovalent Semiconductors and Devices

EP7 Material and Device Frontiers for Integrated Photonics

EP8 Resonant Optics-Fundamentals and Applications

EP9 Materials and Processes for Nonlinear Optics

EP10 Optoelectronic Devices of Two-Dimensional (2D) Materials

EP11 Novel Materials for End-of-Roadmap Devices in Logic, Power and Memory

EP12 Materials Frontiers in Semiconductor Advanced Packaging

EP13 Tailoring Superconductors-

Materials and Devices from Basic Science to Applications

EP14 Materials for Next-Generation Displays

EP15 Diamond Power Electronic Devices

\section{MATERIALS DESIGN}

MD1 Materials, Interfaces and Devices by Design

MD2 Tuning Properties by Elastic Strain EngineeringFrom Modeling to Making and Measuring

MD3 Functional Oxide Heterostructures by Design

MD4 Phase-Change Materials and Applications

MD5 Fundamentals of Organic SemiconductorsSynthesis, Morphology, Devices and Theory

MD6 Electronic Textiles

MD7 Advances in Lanthanide Materials for Imaging, Sensing, Optoelectronics and Recovery/Recycling

MD8 Multiscale Behavior of Materials in Extreme Environments

MD9 Magnetic Materials-From Fundamentals to Applications

MD10 Micro-Assembly Technologies

\section{NANOTECHNOLOGY}

NT1 Functional Nanostructures and Metamaterials for Solar Energy and Novel Optical Phenomena

NT2 Oxide and Chalcogenide-Based Thin Films and Nanostructures for Electronics and Energy Applications

NT3 Carbon Nanofluidics

NT4 Emerging Non-Graphene 2D Materials

NT5 Nanodiamonds-Fundamentals and Applications

NT6 Colloidal Nanoparticles-From Synthesis to Applications

NT7 Nanoparticle Characterization and Removal

NT8 Silicon Nanostructures-Doping, Interface Effects and Sensing

\section{SOFT MATERIALS AND BIOMATERIALS}

SM1 Liquid Crystalline Materials-Displays and Beyond

SM2 Bioinspired Dynamic Materials—Synthesis, Engineering and Applications

SM3 Soft Materials for Compliant and Bioinspired Electronics

SM4 Engineering Biointerfaces with Nanomaterials

SM5 Surfaces and Interfaces for Biomaterials

SM6 Transient and Biologically-Inspired Electronics

SM7 Future Healthcare Needs through Biomaterials, Bioengineering and the Cellular Building Block

SM8 Bioinspired Metal Nanoparticles-Synthesis, Properties and Application SM9 Structure and Properties of Biological Materials and Bioinspired Designs SM10 Biofabrication-Based Biomaterials and Tissues 


\section{Recent Titles}

from the Materials Research Society and Cambridge University Press

\section{Book Collection}

Fundamentals of Materials for Energy and Environmental Sustainability

EDITORS: David S. Ginley and David Cahen ISBN: 9781107000230

List Price: $\$ 110.00$

MRS Member Discount Price: $\$ 88.00$

A unique, interdisciplinary textbook with contributions from more than 100 experts in energy and the environment from around the world.

www.cambridge.org/ginley

Introduction to Computational Materials Science Fundamentals to Applications

AUTHOR: Richard LeSar

ISBN: 9780521845878

List Price: $\$ 100.00$

MRS Member Discount Price: $\$ 80.00$

Emphasizing essential methods and universal principles, this textbook provides everything students need to understand the basics of simulating materials behavior.

www.cambridge.org/lesar

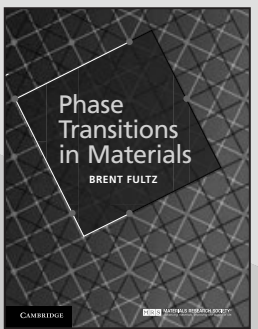

Phase Transitions in Materials

AUTHOR: Brent Fultz

ISBN: 9781107067240

List Price: $\$ 90.00$

MRS Member Discount Price: $\$ 72.00$

Offering a fresh viewpoint on phase changes and the thermodynamics of materials, this textbook covers the thermodynamics and kinetics of the most important phase transitions in materials science, spanning classical metallurgy through to nanoscience and quantum phase transitions.

www.cambridge.org/fultz

Biological Materials Science

Biological Materials, Bioinspired Materials, and Biomaterials

AUTHORS: Marc André Meyers and Po-Yu Chen

ISBN: 978110701045

List Price: $\$ 99.00$

MRS Member Discount Price: $\$ 79.00$

Split into three sections-Basic Biology Principles, Biological Materials, and Bioinspired Materials and Biomimetics-this book presents biological materials along with the structural and functional classification of biopolymers, bioelastomers, foams, and ceramic composites.

www.cambridge.org/bms

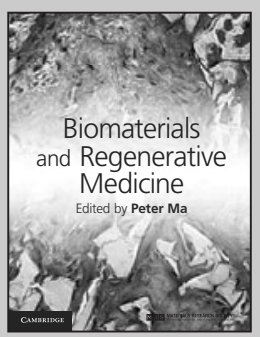

Biomaterials and Regenerative Medicine

EDITOR: Peter Ma

ISBN: 9781107012097

List Price: $\$ 185.00$

MRS Member Discount Price: $\$ 148.00$

Emphasizing basic principles and methodology, this book covers stem cell interactions, fabrication technologies, design principles, physical characterization and biological evaluation, across a broad variety of systems and biomaterials.

www.cambridge.org/biomaterials

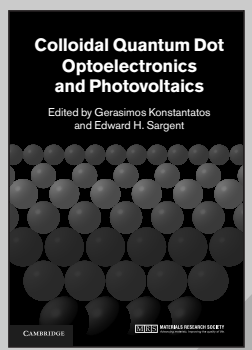

Colloidal Quantum Dot Optoelectronics and Photovoltaics

EDITORS: Gerasimos Konstantatos and Edward H. Sargent ISBN: 9780521198264

List Price: $\$ 130.00$

MRS Member Discount Price: $\$ 104.00$

Written in an accessible style by the world's leading experts, this book captures the most up-to-date research in colloidal quantum dot devices.

www.cambridge.org/colloidal

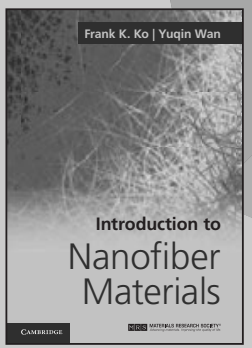

Introduction to Nanofiber Materials

AUTHORS: Frank K. Ko and Yuqin Wan

ISBN: 9780521879835

List Price: $\$ 99.00$

MRS Member Discount Price: $\$ 79.00$

Presenting the latest coverage of the fundamentals and applications of nanofibrous materials and their structures for graduate students and researchers, this book bridges the communication gap between fiber technologists and materials scientists and engineers.

www.cambridge.org/nanofiber

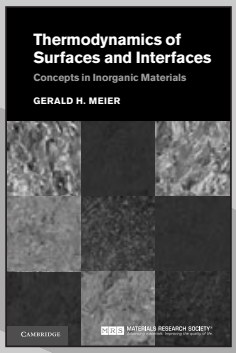

Thermodynamics of Surfaces and Interfaces Concepts in Inorganic Materials

AUTHOR: Gerald H. Meier

ISBN: 9780521879088

List Price: $\$ 120.00$

MRS Member Discount Price: $\$ 96.00$

This book provides an accessible yet rigorous discussion of the thermodynamics of surfaces and interfaces, delivering a comprehensive guide without an overwhelming amount of mathematics.

www.cambridge.org/meier 


\section{MATERIALS RESEARCH SOCIETY ${ }^{\circledR}$}

\section{Board of Directors Officers}

Oliver Kraft, President

Tia Benson Tolle, Past President

Kristi S. Anseth, Vice President

Sean J. Hearne, Secretary

Michael R. Fitzsimmons, Treasurer

Todd M. Osman, Executive Director

\section{Directors}

Charles T. Black

Alexandra Boltasseva

C. Jeffrey Brinker

David Cahen

Stephen J. Eglash

Sossina M. Haile

Andrea M. Hodge

Hideo Hosono

Karen L. Kavanagh
Fiona C. Meldrum

Kornelius Nielsch

Christine Ortiz

David J. Parrillo

Sabrina Sartori

Eric A. Stach

Loucas Tsakalakos

Anke Weidenkaff

\section{Publications Committee}

R.A. Vaia, Chair

S.P. Baker, Editors Subcommittee

A.J. Hurd, New Publication Products Subcommittee

J.M. Phillips, Publications Quality Subcommittee

\section{MRS Committee Chairs}

B.M. Clemens, Academic Affairs

A. Polman, Awards

K. Whittlesey, Government Affairs

D.S. Ginley, Meetings Committee
Y. Chabal, Member Engagement

R.A. Vaia, Publications

E. Kupp, Public Outreach

\section{MRS Headquarters}

T.M. Osman, Executive Director

J.A. Dillen, Director of Finance and Administration

D. Dozier, Director of Government Affairs

P.A. Hastings, Director of Meeting Activities

E.M. Kiley, Director of Communications

\section{Journal of Materials Research Founding Sponsors}

Allied-Signal Inc.

Xerox Corporation

\begin{abstract}
About the Materials Research Society
The Materials Research Society (MRS ${ }^{\circledR}$ ) is a not-for-profit scientific association founded in 1973 to promote interdisciplinary goal-oriented basic research on materials of technological importance. Membership in the Society includes over 16,000 scientists from industrial, government, and university research laboratories in the United States and abroad.

The Society's interdisciplinary approach to the exchange of technical information is qualitatively different from that provided by single-discipline professional societies because it promotes technical exchange across the various fields of science affecting materials development. MRS sponsors two major international annual meetings encompassing many topical symposia, as well as numerous single-topic scientific meetings each year. It recognizes professional and technical excellence, conducts tutorials, and fosters technical exchange in various local geographical regions through Section activities and Student Chapters on university campuses.
\end{abstract}

MRS publishes symposia proceedings, the MRS Bulletin, and other volumes on current scientific developments. The Journal of Materials Research, the archival journal spanning fundamental developments in materials science, is published twenty-four times a year by Cambridge University Press for the MRS. MRS Communications is a full-color letters and prospectives journal focused on groundbreaking work across the spectrum of materials research. MRS Energy \& Sustainability-A Review Journal publishes reviews on key topics in materials research and development as they relate to energy and sustainability.

MRS regular and student members may subscribe to Journal of Materials Research. See inside front cover for subscription rates for Journal of Materials Research.

MRS is an Affiliated Society of the American Institute of Physics and participates in the international arena of materials research through associations with professional organizations.

For further information on the Society's activities, contact MRS Headquarters, 506 Keystone Drive, Warrendale, PA 15086-7573; telephone (724) 779-3003; fax (724) 779-8313. 

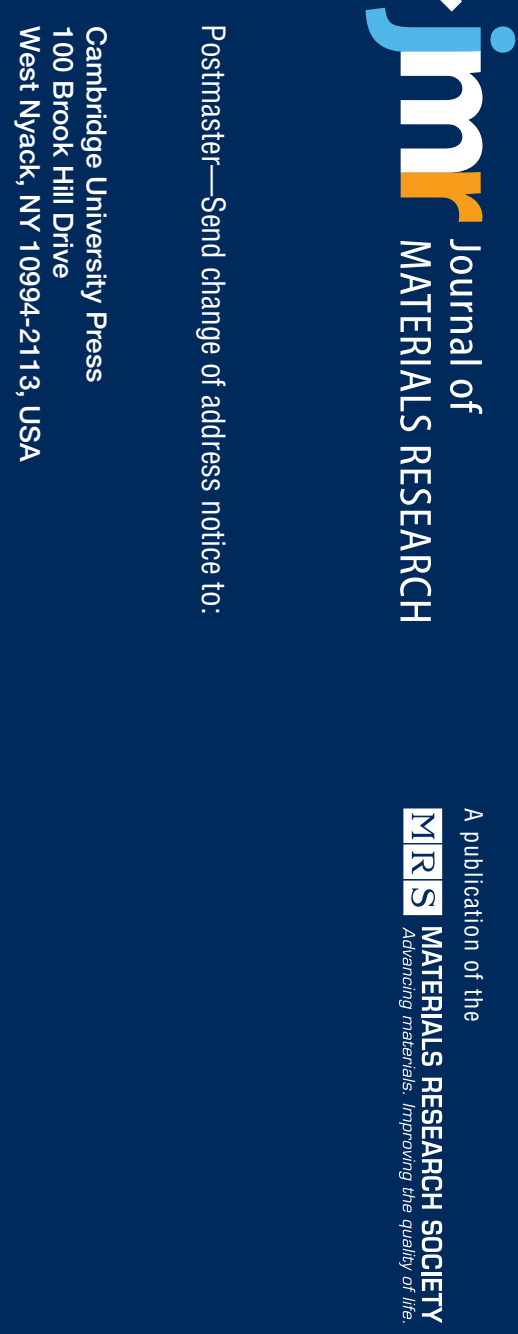

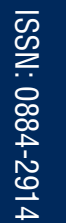

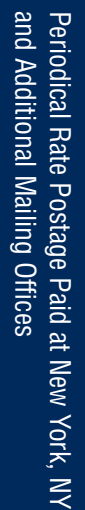

